\title{
Nilai-Nilai Moral dalam Teks Anekdot Abdurrahman Wahid (Gus Dur) dan Implikasinya bagi Pembelajaran Bahasa Indonesia di Sekolah
}

\author{
Meylinda Fillia Pantow, Donal M. Ratu, Oldie S. Meruntu
}

\author{
Jurusan Pendidikan Bahasa dan Sastra Indonesia, Fakultas Bahasa dan Seni, Universitas Negeri \\ Manado
}

pantow.meylindafi@gmail.com,donalratu@unima.ac.id,oldiemeruntu@unima.ac.id

\begin{abstract}
Abstrak. Penelitian ini bertujuan (1) mendeskripsikan nilai-nilai moral yang terdapat dalam teks anekdot Gus Dur, yang meliputi lima cerita, yakni: Siapa yang Paling Hebat?, Sopir Metromini dan Juruh Dakwah, Santri Dilarang Merokok,, Dialog Presiden dengan Tuhan, dan DPR Turun Pangkat, dan (2) mendeskripsikan implikasi hasil penelitian bagi pembelajaran bahasa Indonesia di sekolah. Penelitian ini menggunakan jenis rancangan metode kualitatif dan menggunakan teknik analisis isi (content analysis). Intrumen penelitian menggunakan jenis human instrument dan sumber data penelitian adalah anekdot Gus Dur, yang diambil dari "39 Humor yang Lucu Gus Dur". Berdasarkan hasil penelitian dan pembahasan, diperoleh yaitu: 1) nilai-nilai moral yang terdapat dalam teks anekdot "Siapa yang Paling Hebat", antara lain: keberanian, loyalitas atau kesetian pada tugas, dan tidak boleh sombong. Nilai-nilai moral yang terdapat dalam teks anekdot "Sopir Metromini dan Juru Dakwah" siapun manusia di hadapan Tuhan sama dan tidak menjadi sombong rohani. Nilai-nilai moral dalam teks anekdot "Santri Dilarang Merokok" mematuhi aturan atau larangan dan membuktikan kesalahan seorang anak didik secara langsung. Nilai-nilai moral dalam teks anekdot "Dialog dangan Tuhan" adalah bersikap toleran, menghargai, dan menghormati keyakinan dan idiologi bangsa lain dan keyakinan orang lain. Teks anekdot Gus Dur yang berjudul "DPR Turun Pangkat" yakni etika berbicara dan menghargai perbedaan pendapat. 2) Nilai-nilai moral dalam teks anekdot Gus Dur memberikan implikasi terhadap pembelajaran teks anekdot di sekolah. Relevansi hasil penelitian mengenai nilai-nilai moral dalam teks anekdot Gus Dur dengan pengajaran teks anekdot, karena menyajikan nilainilai kehidupan sehingga anekdot dapat dijadikan sumber pengajaran nilai moral atau nilai kehidupan.
\end{abstract}

Kata Kunci: Nilai Moral, Teks, Anekdot

\section{PENDAHULUAN}

Sorotan tentang perilaku hidup individu dan sekelompok orang dan berbagai persoalan kehidupan manusia menjadi lahan bagi para penulis kreatif untuk menghasilkan sebuah karya. Salah satu karya kreatif yang dihasilkan oleh manusia adalah anekdot. Disebut kreatif, karena isi ceritanya singkat, unik, dan menarik.

Mahsun (2014:25) memasukkan anekdot ke dalam genre cerita, di mana teks anekdot memiliki tujuan sosial yang sama dengan teks cerita ulang. Hanya saja peristiwa yang ditampilkan membuat partisipan yang mengalaminya merasa jengkel atau konyol. Sejalan dengan ini, dikutip dari (https://brainly.co.id) anekdot adalah "cerita yang bersifat humor atau lelucon, bersifat menyindir, memiliki tujuan untuk membangkitkan tawa pembacanya, sebagai saran penghibur dan pengeritik".

Anekdot bukanlah sekedar cerita tanpa makna, namun sesungguhnya menyajikan nilai-nilai kehidupan, sehingga anekdot dapat dijadikan sumber pengajaran nilai di tengah masyarakat, sekolah, dan keluarga. Dalam berbagai kesempatan, misalnya dalam sebuah acara yang formal dan tidak formal, ketika seorang pembicara membawakan sambutan, pidato, atau khotbah, pembicara sering menjadikan anekdot sebagai cara menyampaikan pesan supaya pendengar tetap antusias mendengarkan apa yang dia sampaikan. Tidak terkecuali, semua kalangan mulai dari kelompok anak-anak, muda-mudi, dan orang tua saat berkumpul sering beranekdot untuk membuat susana menjadi nyaman dan tema anekdot yang diangkat sering bertalian dengan masalah praktis kehidupan. Bahkan, di sekolah teks anekdot 
adalah salah satu teks yang wajib dipelajari sebagaimana tercantum dalam silabus mata pelajaran bahasa Indonesia Kurikulum 2013 untuk siswa kelas X SMA. Dalam Kompetensi Inti 3, dijabarkan kompetensi dasar (KD) pembelajaran tentang teks anekdot, yakni "mengintepretasi makna teks enekdot".

Sesungguhnya, anekdot dapat dijadikan sarana untuk menyebarkan tentang berbagai nilai kehidupan yang bertalian dengan moral. Misalnya mengajarkan nilai kemajemukan (perbedaan), kepatuhan kepada orang tua, menghormati sesama, bekerja keras, bersikap rendah hati, dan menolong sesama (Burns, 2004:45). Anekdot ketika disampaikan bukan hanya sekedar membuat orang tertawa, tetapi menjadi cara menyampaikan pesan yang isinya agak tajam dan mengeritik, yang bisa saja membuat kalangan tertentu tersinggung.

Dapat dikatakan bahwa anekdot sebagai sebuah cerita memiliki daya tarik bukan sekedar sarana hiburan semata, tetapi lebih dari itu dapat dijadikan menyebarkan nilai-nilai kemanusiaan dan juga media belajar bagi anak. Di sinilah keunikan sekaligus keunggulan teks anekdot yang sering diceritakan dalam setiap kesempatan untuk bersenda gurau, tetapi juga pencair ketegangan dalam acara formal di saat dosen atau guru mengajara ataupun ketika pimpinan memberikan arahan kepada bawahan.

Salah satu tokoh publik yang gemar beranekdot adalah Kyai Haji Abdurrahman Wahid yang lebih akrab dipanggil Gus Dur. Gus Dur yang diberi gelar Bapak Kemajemukan Indonesia adalah sosok yang fenomenal, pernah menjadi ketua NU bahkan, yang luar biasa menjadi Presiden Indonesia ke-4. Sosok Gus Dur sering menjadikan anekdot untuk menghibur, tetapi juga untuk menyindir. Gus Dur adalah Kyai dan presiden humoris. Saat berbicara, dia tidak segan menyelipkan anekdot yang membuat pendegar tertawa. Bagi Gus Dur, "dengan lelucon, kita bisa sejenak melupkan kesulitan hidup, dengar humor pikiran kita jadi sehat" (Gusdur.net.).

Anekdot-anekdot yang telah dihasilkan oleh Gus Dur dikumpulkan oleh para pengagum/pengikutnya baik dalam buku, maupun dipublikasikan secara daring. Hal ini dapat kita temukan dalam "39 Humor yang Lucu (https//:muslimoderat.net.). Bahkan, teks anekdot yang dihasilkan Gus Dur telah dijadikan kajian ilmiah untuk penyusunan karya ilmiah, seperti skripsi. Penulis juga tertarik untuk melakukan kajian ilmiah mengenai nilai-nilai moral yang terdapat dalam anekdot Dus Dur. Dalam laman "Pengajar Co Id. dijelaskan "Nilai moral adalah nilai-nilai yang berkaitan dengan perbuatan baik serta buruk yang menjadi pedoman kehidupan manusia secara umum (https://pengajar.co.id/nilai-moral-adalah/). Jadi, nilai moral sesungguhnya merupakan nilai yang dapat menggerakkan manusia melakukan sesuatu yang baik, sehingga nilai moral ini cenderung mengatur dan mengarahkan tindakan individu dalam kehidupan sehari-hari, sehingga tercipta tatanan kehidupan yang baik.

Penelitian ini difokuskan pada penggalian nilai-nilai moral dalam anekdot Gus Dur, yang meliputi Lima Cerita, yakni: Siapa yang Paling Hebat?, Sopir Metromini dan Juruh Dakwah, Ikan Curian Gus Dur jadi Halal, Dialog Presiden dengan Tuhan, dan DPR Turun Pangkat dan implikasinya terhadap pembelajaran teks anekdot di sekolah.

\section{METODE}

Penelitian ini menggunakan jenis rancangan metode kualitatif. Metode kualitatif digunakan karena objek dalam penelitian ini berupa teks anekdot dan jenis datanya adalah data verbal. Sumber data penelitian ini adalah anekdot Gus Dur, yang meliputi lima cerita, yakni: Siapa yang Paling Hebat?, Sopir Metromini dan Juruh Dakwah, Ikan Curian Gus Dur jadi Halal, Dialog Presiden dengan Tuhan, dan DPR Turun Pangkat? Yang diambil dari "39 Humor yang Lucu Gus Dur" (https//:muslimoderat.net...)

Penelitian ini menggunakan teknik analisis isi (content analysis), yakni teknik yang menekankan membaca secara mendalam dan berulang lima teks anekdot Gus Dur yang dijadikan sebagai objek penelitian. Intrumen penelitian ini menggunakan jenis human instrument, yaitu peneliti sendiri bertindak sebagai instrument, yang mengumpulkan data, melakukan analisis data, memeriksa keabsahan data, dan menarik kesimpulan hasil penelitian. Teknik analisis data yang digunakan dalam penelitian ini menggunakan teknik analisis data kualitatif , yakni: 1)Menandai kalimat-kalimat atau pargraf-pargraf dalam teks anekdot yang mengungkapkan nilai-nilai moral. 2) Menyajikan data secara sistematis mengenai nilai-nilai moral yang ditemukan dalam teks. 3) Memeriksa dan melakukan analisis nilai-nilai moral yang telah ditemukan dalam teks. 4) Menarik kesimpulan. 


\section{HASIL DAN PEMBAHASAN}

\section{Nilai-nilai Moral dalam Teks Anekdot Gus Dur}

1) Nilai Moral dalam Teks Anekdot "Siapa yang Paling Hebat?"

\section{a. Keberanian}

Nilai keberanian dalam teks anekdot "Siapa yang Paling Hebat" ditunjukkan oleh dua prajurit yang berasal dari Amerika Serikat dan Jepang. Keberanian menantang bahaya mereka tunjukkan dengan gagahnya saat mereka berani berenang mengintari kapal yang mereka tumpangi sesuai perintah kepala negara masing-masing. Padahal, di sekitar kapal ada ikan-ikan hiu ganas yang sedang kelaparan. Prajurit Amerika berani berenang mengintari kapal sebanyak sepuluh kali, seperti pada data berikut ini.

Bill Clinton (AS) : Kalau Anda tahu ... prajurit kami adalah yang terberani di seluruh dunia ... Mayor .. sini deh ... coba kamu berenang keliling ini kapal sepuluh kali.

Mayor $\quad$ : (walau tahu ada hiu) siap pak, demia "The Star Spangled Banner" saya siap ,„, (akhirnya dia terjun dan mengelilingi kapal 10 kali sambil dikejar hiu).

Mayor : (naik kapal dan menghadap) Selesai pak!!! Long Live America!!

Clinton : Hebat kamu, kembali ke pasukan!

Keberanian yang sama ditunjukkan pula oleh prajurit dari Jepang, bahkan perintah kepala negaranya lebih gila lagi. Kalau prajurit Amerika hanya diminta presidennya berenang mengintari kapal sebanyak sepuluh kali, maka prajurit Jepang diperintahkan mengintari kapalnya sebanyak lima puluh kali. Perintah yang berbahaya ini diterima oleh sang prajurit demi kehormatan negaranya. Sang prajurit terjun ke laut berenang mengintari kapal sebanyak lima puluh kali sambil dikejar ikan-ikan hiu yang kelaparan.

Nilai keberanian yang ditunjukkan oleh kedua prajurit dari AS dan Jepang pada data-data di atas menunjukkan bahwa mereka rela mempertaruhkan nyawa untuk membela kehormatan negaranya. Perintah Presiden yang tidak masuk akal, karena sangat berbahaya tidak dibantah mereka, karena mereka tahu yang memberi perintah adala kepala negara, simbol kehormatan suatu negara. Berbeda denga apa yang ditunjukkan prajurit Indonesia, bukan melaksanakan perintah presiden negaranya, tetapi malah mengatakan perintah presidennya gila, dan tidak punya otak, malah pergi meninggalkan presidennya.

b. Nilai Loyalitas atau Kesetiaan

Nilai kesetiaan atau loyalitas bertalian dengan kesediaan dan kerelaan melaksanakan tugas dan tanggung jawab pada pekerjaan yang diberikan oleh atasan. Nilai kesetiaan atau loyalitas yang tergambar dalam anekdot Gus Dur "Siapa yang Paling Hebat" bertalian dengan tugas seorang prajurit menjaga kehormatan bangsa dan negara, yang ditandai oleh kepatuhan memenuhi perintah presiden sebagai kepala negara dan pemerintahan.

Nilai kesetiaan atau loyalitas dalam teks anekdot "Siapa yang Paling Hebat ditunjukkan oleh dua prajurit AS dan Jepang. Prajurit AS yang diperintahkan oleh Presidennya untuk berenang mengarungi kapal sebanyak sepuluh kali, tidak membantah sepatah kata pun, walaupun di tahu bahaya yang harus diterima malaksanakan perintah tersebut. Perintah itu walaupun tidak masuk akal dan sangat berbahaya, prajurit AS tidak membantahnya. Dia tahu kesetiaan atau loyalitas kepada presidennya adalah juga bentuk kesetiaannya pada negara. Mengintari kapal yang besar sebanyak sepuluh kali yang di sekitarnya terdapat ikan-ikan hiu yang ganas, bukan pekerjaan mudah, tetapi karena yang memberi perintah itu presiden, dia dengan ikhlas melaksanakan perintah tersebut.

Dari data di atas tergambar bahwa si Mayor, prajurit AS pemberani mengatakan, Siap Pak, demi “The Star Spangled Banner" saya siap. The Star Spangled Banner" berarti “Panji Berhiaskan Bintang" adalah judul lagu kebangsaan AS. Ungkapan mayor ini bermakna perintah presiden adalah demi kejayaan bendara sebagai lambang kebanggaan dan kejayaan bangsa AS. Bahkan, setelah selesai melaksanakan perintah presiden, sang prajurit mengatakan, "Selesai pak!!! Long Live America!" 
(Amerika hidup Selamanya). Loyalitas prajurit AS pada presiden dan negaranya adalah sikap patriotisme, yang rela mempertaruhkan jiwa dan raganya untuk bangsa.

Kesetiaan dan loyalitas terhadap perintah presiden ditunjukkan juga oleh parajurit, prajurit Jepang. Si prajurit tahu yang memberi perintah adalah presiden, hal itu sama dengan tugas negara. Ketika diperintahkan untuk mengintari kapal lima puluh kali, sersan langsung menyatakan siap.

Menarik sekali pesan nilai kehidupan teks anekdot Gus Dur, yang menampilkan nilai keberanian dan loyalitas/kesetiaan kepada pemimpin negara yang merupakan simbol negara. Sebaliknya, ketika Gus Dur berkisah tentang prajurit Indonesia yang diwakili kopral, maka Gus Dur memberikan sindiran, tetapi tidak bermaksud merendahkan keberanian dan kesetiaan prajurit/tentara Indonesia yang tidak berani dan loyal. Sebaliknya, menyindir segelintir prajurit Indonesia yang sering lupa pada sumpah tentara Indonesia, yang setia pada tugas dan panggilan negara. Dalam teks ini, membandel, menolak perintah, dan meninggalkan tugas, adalah suatu "kehebatan" bagi Gus Dur, dibanding prajurit AS dan Jepang.

\section{2) Nilai Moral dalam Teks Anekdot "Sopir Metromini dan Juru Dakwah"}

Teks anekdot Gus Dur "Sopir Metromini dan Juru Dakwah" mengisahkan kisah seorang sopir metromini dengan Gus Dur sebagai juru dakwah. Pada saat mereka berada di akherat, sopir metromini mendapatkan kamar mewah yang terbuat dari emas, sedangkan Gus Dur yang mantan presiden dan juga juru dakwah hanya mendapat kamar kecil yang peralatannya terubuat dari kayu. Gus Dur protes kepada Malaekat. Mengapa dia yang mantan presiden dan juru dakwah hanya mendapat kamar yang lebih rendah di banding sopir metromini? Lalu, dengan tenang Malaekat menjawab bahwa pada saat Gus Dur berceramah membuat semua orang ngantuk dan tertidur, sehingga melupakan Tuhan. Sebaliknya, sopir metromini mengendarai mobilnya dengan ngebut membuat mereka mengingat Tuhan dan berdoa.

Teks anekdot "Sopir Metromini dan Juru Dakwah" berisi sindiran mengenai praktik hidup beragama, karena ada orang yang merasa statusnya lebih besar, penting, dan terhormat dibanding orang lain. Padahal di hadapan Tuhan semua manusia sama, juru dakwah, kiyai, pendeta semua di hadapan Tuhan sama. Dalam cerita ini terkandung nilai moral yang penting, seperti diuraikan berikut ini.

\section{a. Manusia di Hadapan Tuhan Sama}

Teks anekdot "Sopir Metromini dan Juru Dakwah" mengungkapkan nilai moral yang penting bahwa siapa pun manusia di hadapan Tuhan sama. Tuhan tidak memandang status seseorang di dunia ini, karena pada saat di akherat semua status manusia, apakah dia pemimpin agama, juru dakwah, pejabat, pengusaha, orang kaya, orang berpendidikan, sopir, buruh bangunan, orang miskin, dan pengamen tidak berguna. Apa yang dipakai untuk menghakimi seseorang di akherat adalah perbuatannya.

Dalam cerita ini sopir metromini, yang dalam status sosial dianggap rendah, tetapi malaekat yang menjaga pintu akherat memberikan kamar luas, yang terbuat dari emas, seperti tergambar pada data berikut.

Di pintu akherat seorang malaikat menanyai seorang sopir Metro Mini. "Apa kerjamu selama di dunia?" tanya malaikat itu.

"Saya sopir Metro Mini, Pak." Lalu malaikat itu memberikan kamar yang mewah untuk sopir Metro tersebut dan peralatan yang terbuat dari emas.

Sementara itu, juru dakwah yang adalah Gus Dur sendiri, yang juga mantan presiden ketika ditanyai oleh malaekat di pintu akherat, dengan bangga menyebut status atau jabatannya di dunia, yakni juru dakwah dan mantan prsiden. Akan tetapi, Malaekat hanya memberikan kamar kecil yang terbuat dari kayu kepada Gus Dur. Gus Dur pun protes, karena dia merasa diperlakukan tidak adil.

\section{b. Tidak Menjadi Sombong Rohani}

Tidak menjadi sombong rohani merupakan nilai moral penting yang terungkap dalam teks anekdot "Sopir Metromini dan Juru Dakwah". Di tengah masyarakat sering dijumpai ada orang yang menjad sombong rohani, karena status yang disandang secara keagamaan membuat mereka merasa lebih terhormat, baik, dan suci di hadapan orang lain. Status seperti rohaniwan, seperti kiyai, juru dakwah, pendeta dengan pengetahuan teologis yang hebat, apalagi ditambah banyak pengikut, kadang membuat lupa diri. Antara apa yang dikhotbahkan dan diajarkan kepada orang banyak, berbeda dengan sikapnya, 
seperti mudah menghina orang lain, menganggap diri bersih dan suci, sementara menganggap diri orang lain kotor dan rendah. Gus Dur yang adalah mantan presiden dan sebagai juru dakwah ternyata tidak mendapat tempat yang lebih baik dan besar dibanding dengan sopir metromini. Gus Dur dengan sarkatisnya menyindir, seorang juru dakwah ketika berceramah membuat orang tertidur dan melupkan Tuhan. Sebaliknya, sopir metromini karena mengendarai monbilnya dengan ngebut, membuat penumpangnya mengingat Tuhan dan berdoa karena takut mengalami kecelakaan.

3) Nilai Moral dalam Teks Anekdot "Santri Dilarang Merokok"

Nilai moral yang terungkap dari teks anekdot "Santri Dilarang Merokok" diuraikan berikut ini.

\section{a. Mematuhi Larangan}

Setiap santri diwajibkan mematuhi peraturan yang ditetapkan oleh pengelola pondok pesantren. Salah satu larangan yang umum berlaku adalah santri dilarang merokok. Namun, tidak semua santri mematuhi larangan yang dibuat, tetapi suka melanggar, karena sikap bengal dan sulit diatur. Dalam teks anekdot ini terungkap bahwa bila suka melanggar larangan akan mendapat sesuatu. Kiyai Fattah melakukan strategi jitu untuk membuktikan dan menangkap tangan santrinya yang merokok.

Pada saat lampu listrik padam di pesanteren, Kiyai Fattah ke luar gedung dan merokok. Seorang santri yang jalan-jalan ke luar pondok melihat Kiyai Fattah yang tidak diketahuinya, karena suasana gelap. Si Santri ini mengira, itu adalah seniorya. Dia mendekati Kiyai Fattah, yang dia kira senionya. Si Santri, bertanya lagi nyedot ya kang? Kiyai Fattaah tidak menjawab apapun dan memberikan rokok yang dihisapnya kepada santri tersebut. Si santripun langsung mengambil rokok tersebut. Saat dia menyedot rokok apinya membesar dan mengeluarkan cahaya, sehingga dia melihat orang yang dia kira seniornya, ternyata adalah Kiyai Fattah yang tak lain pengasuh pondok pesantren. Betapa takutnya si santri tersebut dan lari tunggang langgang, seperti tergambar pada data di bawah ini.

"Nyedot, Kang?" sapa si santri sambil menghampiri "senior"-nya yang sedang asyik merokok itu. Langsung saja orang itu memberikan rokok yang sedang dihisapnya kepada sang "yunior". Saat dihisap, bara rokok itu membesar, sehingga si santri mengenali wajah orang tadi. Saking takutnya, santri itu langsung lari tunggang langgang sambil membawa rokok pinjamannya. "Hai, rokokku jangan dibawa!" teriak Kiai Fatta.

Dari data di atas menggambarkan bahwa sedapat-dapatnya orang menyembunyikan pelanggaran atau kesalahan akan diketahui juga. Sikap santri yang tertangkap tangan merokok pasti mendapat hukuman sesuai aturan yang berlaku di pondok pesantren tersebut.

\section{b. Membuktikan Kesalahan Orang Secara Langsung}

Nilai moral lain yang terdapat dalam teks anekdot "Santri Dilarang Merokok" adalah bagaimana membuktikan kesalahan seorang anak didik secara langsung. Kiyai Fattah sebagai pengasuh dan guru yang dihormati oleh para santrinya, tidak hanya sekedar mendengar laporan mengenai anak didiknya yang melanggar peraturan, khususnya larangan untuk merokok.

Kiyai Fattah dengan kiatnya yang jitu, membuktikan salah satu santrinya yang diketahui merokok. Dari kiat Kiyai ini dia dapat membuktikan laporan mengenai para santrinya yang diketahui sudah merokok. Dengan demikian, hal ini dilakukan supaya tidak menjadi tuduhan atau fitnah tanpa bukti.

\section{4) Nilai Moral Teks Anekdot "Dialog Presiden dengan Tuhan"}

Teks anekdot "Dialog dangan Tuhan" mengisahkan empat kepala negara yang berdialog dengan Tuhan meminta kemakmuran bagi negara yang mereka pimpin. Keempat kepala negara atau presiden tersebut adalah Ronald Reagan Presiden Amerika Serikat (AS), Syarkozy Presiden Perancis, Tony Balir Perdana Menteri Inggris, dan Gus Dur Presiden Indonesia. Pesan yang terungkap dari cerita ini adalah klaim sebagai negara beragama Muslim terbesar di dunia, tidak seharusnya menjadi lebih baik dari bangsa lain, yang sering dituduh liberal, sekuler dan kafir. Nilai moral yang terkandung dalam teks anekdot ini dipaparkan berikut ini. 


\section{a. Toleransi}

Teks anekdot "Dialog dengan Tuhan" mengandung nilai moral yang penting, yaitu "bersikap toleran" menghargai atau menghormati keyakinan dalam hal ini idiologi bangsa lain". Gus Dur, menyindar klaim kebenaran sepihak oleh segelintir orang Indonesia terhadap bangsa Amerika dan Eropa yang dituduh liberal dan sekuler. Segelintir orang di Indonesia menunjkkan mereka anti Amerika dan Eropa, bahkan menuduh mereka kafir. Ternyata, dalam anekdot "Dialog dengan Tuhan", doa Presiden AS, Presiden Perancis, dan Perdana Menteri Inggrislah yang didengar oleh Tuhan, sperti tergambar pada data berikut ini.

a. Ronald Reagen (AS), " Tuhan, kapan negara kami makmur?, Tuhan jawab," 20 tahun lagi". Presiden AS menangis.

b. Presiden Syarkozy ( Prancis), "Tuhan, kapan negara Prancis makmur?, Tuhan menjawab, " 25 tahun lagi", Mendengar jawaban Tuhan, Presiden Prancis menangis.

c. Tony Blair ( PM. Inggris ). " Tuhan, kapan negara Inggeris bisa makmur", Tuhan menjawab," 20 tahun lagi”, PM. Tony Blair ikut juga menangis.

Dari data di atas terungkap, bahwa doa yang dinaikkan oleh tiga kepala negara, yakni Amerika Serikat (AS), Perancis, dan Inggris dijawab oleh Tuhan. Reaksi ketiga kepala negara tersebut adalah menangis karena doa mereka dijawab oleh Tuhan. Dari jawaban doa yang mereka naikkan dan reaksi ketiga kepala negara tersebut memberikan pesan, penting sekali menghargai toleransi, karena bukan manusia yang dapat menilai seseorang benar di hadapan Tuhan, tetapi Tuhanlah yang menilai siapa yang benar dalam pandanganNya. Inilah maksud Gus Dur menyindir pihak-pihak yang sering menunjukkan sikap bermusuhan anti Eropa dan Amerika (Barat).

\section{b. Jangan Menghakimi Sesama}

Anekdot "Dialog Presiden dengan Tuhan" menunjukkan pikiran Gus Dur yang moderat. Gus Dur tidak terjebak pada klaim kebenaran sepihak tentang keyakinan beragama. Gus Dur menolak klaim kebenaran sepihak oleh orang-orang tertentu yang sering menghakimi orang lain dengan cara pandang berdasarkan perspektif keyakinan agama sendiri. Gus Dur sebagai Presiden dan Ulama yang dihormati di Indonesia, bahkan merasa tidak lebih baik dari ketiga presiden sahabatnya. Ini yang dia maksudkan, Tuhan tidak menjawab doanya, bahkan Tuhanlah yang menangis ketika Gus Dur menaikkan doa permohonan meminta kemakmuran bagi negaranya. Doa yang dinaikkan Gus Dur, sebagai Presiden Republik Indonesia, tidak dijawab oleh Tuhan, bahkan membuat Tuhan menangis memberi pesan penting supaya jangan cepat mengklaim diri yang paling benar. Gus Dur sebagai Presiden Republik Indonesia, yang juga sebagai kiyai, dan ulama Islam yang disegani sebagai representasi masyarakat Indonesia menunjukkan bahwa jangan merasa paling benar di hadapan Tuhan, paling suci, dan layak di hadapan Tuhan, karena justru orang yang dianggap tidak benar, tidak suci, dan tidak layak di hadapan Tuhan, justeru doa merekalah yang didengar oleh Tuhan.

Gus Dur yang adalah kiyai dan Ulama dan presiden dari negara yang memiliki jumlah umat islam terbesar di dunia justeru doanya tidak didengar oleh Tuhan, malah membuat Tuhan menangis. Ungkapan yang bernada guyonan dan menyindir, tetapi memiliki pesan penting untuk hidup berdampingan dan saling menghormati sekalipun berbeda keyakinan beragama dan adat istiadat.

\section{5) Nilai Moral dalam Teks Anekdot "DPR Turun Pangkat'}

Anekdot Gus Dur yang berjudul "DPR Turung Pangkat" merupakan respon pada saat Gus Dur menjadi Presiden. Dalam anekdot tersebut Gs Dur menyampaiakan guyonan tentang DPR RI yang terhormat turun pangkat dari TK menjadi Play Goup. Sesungguhnya, guyonan Gus Dur ini terlontar dari sikap saat mereka melaksanakan sidang paripurna yang membahas kenaikan BBM (Bahan Bakar Minyak) pada tahun 2004. Saat sidang berlangsung, terjadi kericuhan antaranggota dewan, bahkan ada anggota yang sempat menaiki meja pimpinan sidang. Sikap mereka yang tidak etis mendapat reaksi dari Gus Dur, yakni menymakan anggota DPR seperti anak-anak yang sekolah di TK, bahkan karena sikap kurang patut, Gus Dur mengatakan anggota DPR yang disebut wakil-wakil rakyat terhormat turun pangkat menjadi Play Group. Dari anekdot "DPR Turun Pangkat" terkandung nilai moral yang penting, yakni memperhatikan etika berbicara dan menghargai pendapat. 


\section{a. Etika berbicara}

DPR sebagai lembaga terhormat yang di dalamnya terdapat orang-orang terbaik pilihan rakyat seharusnya memperhatikan etika berbicara saat bersidang. Sikap mereka berbicara seharusnya dijaga, memperhatikan sopan santun, dan etika. Akan tetapi, pada saat mereka bersidang, mereka sering menampakkan perilaku kekak-kanakan, seperti saling berebutan berbicara, membentak, memukul meja, dan mengeluarkan kata-kata umpatan yang tidak pantas, bahkan ada yang sempat maju menaiki meja pimpinan sidang. Karena itu, perilaku kekanak-kanakan tersebut maka Gus Dur menyebut mereka layaknya Taman Kanak-Kanak yang turn pangkat menjadi Play Group seperti terungkap pada data berikut.

\section{b. Menghargai Pendapat}

Dari anekdot tersebut terungkap juga nilai moral yang penting, yakni bagaimana menghargai pendapat saat berbicara dalam forum resmi. Menghargai perbedaan pendapat adalah esensi dari demokrasi. Perilaku yang saling mencela disertai penggunaan kata-kata yang tidak patut tidak semestinya ditunjukkan oleh anggota DPR. Menghargai pendapat untuk mengambil keputusan dengan cara musywarah dan mufakat sangat penting. Inilah juga maksud ungkapan Gus Dur, "DPR dulu TK, sekarang play group" karena saat berbicara memaksakan kehendak. Jika kehendaknya tidak diterima, menjadi emosi dan marah sehingga mengeluarkan kata-kata umpatan yang tidak pantas.

Hasil penelitian menunjukkan bahwa nilai-nilai moral yang terdapat dalam teks anekdot "Siapa yang Paling Hebat", yakni: keberanian, loyalital atau kesetian pada tugas, dan tidak boleh sombong. Menarik sekali menelaah pesan nilai kehidupan teks anekdot Gus Dur, yang menampilkan nilai keberanian dan loyalitas/kesetiaan kepada pemimpin negara yang merupakan simbol negara. Sebaliknya, ketika Gus Dur berkisah tentang prajurit Indonesia yang diwakili kopral, maka Gus Dur memberikan sindiran, tetapi tidak bermaksud merendahkan keberanian dan kesetiaan prajurit/tentara Indonesia yang tidak berani dan loyal. Sindiran ini penting supaya prajurit Indonesia memperbaiki mentalnya agar dihormati dan disegani oleh prajurit dari bangsa-bangsa lain.

Teks anekdot "Sopir Metromini dan Juru Dakwah" berisi sindiran mengenai praktik hidup beragama, karena ada orang yang merasa statusnya lebih besar, penting, dan terhormat dibanding orang lain. Padahal, di hadapan Tuhan semua manusia sama, juru dakwah, kiyai, pendeta semua di hadapan Tuhan sama. Teks anekdot "Sopir Metromini dan Juru Dakwah" mengungkapkan nilai moral yang penting bahwa siapun manusia di hadapan Tuhan sama. Tuhan tidak memandang status seseorang di dunia ini, karena pada saat di akherat semua status manusia, apakah dia pemimpin agama, juru dakwah, pejabat, pengusaha, orang kaya, orang berpendidikan, sopir, buruh bangunan, orang miskin, dan pengamen sama. Apa yang dipakai untuk menghakimi seseorang di akherat adalah perbuatannya.

Nilai lain yang terungkap dari teks anekdot "Sopir Metromini dan Juru Dakwah" adalah tidak menjadi sombong rohani.

Nilai moral lain yang terdapat dalam teks anekdot "Santri Dilarang Merokok" adalah bagaimana membuktikan kesalahan seorang anak didik secara langsung. Kiyai Fattah sebagai pengasuh dan guru yang dihormati oleh para santrinya, tidak hanya sekedar mendengar laporan mengenai anak didiknya yang melanggar peraturan, khususnya larangan untuk merokok. Kiyai Fattah dengan kiatnya yang jitu, membuktikan salah satu santrinya yang diketahui merokok. Dari kiat Kiyai ini dia dapat membuktikan laporan mengenai para santrinya yang diketahui sudah merokok.

Teks anekdot "Dialog dangan Tuhan" pesan yang terungkap dari cerita ini adalah klaim pihakpihak tertentu di Indonesia bahwa sebagai negara beragama Muslim terbesar di dunia, tidak seharusnya menjadi lebih baik dari bangsa lain, yang sering dituduh liberal, sekuler dan kafir. Bersikap toleran, menghargai, dan menghormati keyakinan dalam hal ini idiologi bangsa lain dan keyakinan orang lain adalah hal yang baik. Gus Dur menyindar klaim kebenaran sepihak oleh segelintir orang terhadap bangsa Amerika dan Eropa yang dituduh liberal dan sekuler. Segelintir orang di Indonesia menunjkkan mereka anti Amerika Eropa, bahkan menuduh mereka kafir. Ternyata, dalam anekdot "Diaolog dengan Tuhan", doa Presiden AS, Presiden Perancis, dan Perdana Menteri Inggris , yang didengar oleh Tuhan. Reaksi ketiga kepala negara tersebut adalah menangis karena doa mereka dijawab oleh Tuhan. Dari jawaban doa yang mereka naikkan dan reaksi ketiga kepala negara tersebut memberikan pesan, penting sekali menghargai toleransi, karena bukan manusia yang dapat menilai seseorang benar di hadapan 
Tuhan, tetapi Tuhanlah yang menilai siapa yang benar dalam pandanganNya. Inilah maksud Gus Dur menyindir pihak-pihak yang sering menunjukkan sikap bermusuhan anti Eropa dan Amerika (Barat).

Teks anekdot Gus Dur yang berjudul "DPR Turun Pangkat" pada saat Gus Dur menjadi populer saat dia menjabat Presiden. Dari anekdot "DPR Turun Pangkat" terkandung nilai moral yang penting, yakni memperhatikan etika berbicara dan menghargai pendapat. Etika berbicara dan menghargai perbedaan pendapat adalah esensi dari demokrasi. Perilaku yang saling mencela disertai penggunaan kata-kata yang tidak patut tidak semestinya ditunjukkan oleh anggota DPR. Berbicara santun dan menghargai pendapat untuk mengambil keputusan dengan cara musywarah dan mufakat sangat penting. Inilah juga maksud ungkapan Gus Dur, "DPR dulu TK, sekarang play group" karena saat berbicara memaksakan kehendak. Jika kehendaknya tidak diterima, menjadi emosi dan marah sehingga mengeluarkan kata-kata umpatan yang tidak pantas.

\section{Implikasi Hasil Penelitian bagi Pembelajaran Teks Anekdot di sekolah}

Pembelajaran berbasis teks untuk mata pelajaran bahasa Indonesia Kurikulum 2013 memasukkan teks anekdot sebagai salah satu jenis teks yang dipelajari. Mahsun (2014:25) memasukkan anekdot ke dalam genre cerita, di mana teks anekdot memiliki tujuan sosial yang sama dengan teks cerita ulang. Hanya saja peristiwa yang ditampilkan membuat partisipan yang mengalaminya merasa jengkel atau konyol. Dikutip dari (https://brainly.co.id) anekdot adalah "cerita yang bersifat humor atau lelucon, bersifat menyindir, memiliki tujuan untuk membangkitkan tawa pembacanya, sebagai saran penghibur dan pengeritik".

Jadi, terkait dengan relevansi pengajaran teks anekdot bagi siswa di sekolah, yakni teks anekdot bukanlah sekedar cerita tanpa makna, namun sesungguhnya menyajikan nilai-nilai kehidupan, sehingga anekdot dapat dijadikan sumber pengajaran nilai moral atau kehidupan. Faktanya, ketika seorang pembicara membawakan sambutan, pidato, atau khotbah, pembicara sering menjadikan anekdot sebagai cara menyampaikan pesan supaya pendengar tetap antusias mendengarkan apa yang dia sampaikan. Ini merupakan cara yang tepat untuk menyampaikan nasihat.

Sebagai salah satu jenis teks yang dipelajari siswa, maka dalam silabus mata pelajaran bahasa Indonesia Kurikulum 2013 untuk siswa kelas X SMA terdapat Kompetensi Inti 3, di mana salah satu kompetensi dasar (KD) pembelajarannya yaitu "mengintepretasi makna teks enekdot". Tentu saja, dasar pemikiran teks anekdot diajarkan karena dapat dijadikan sarana untuk menyebarkan berbagai nilai kehidupan yang bertalian dengan moral. Misalnya mengajarkan nilai kemajemukan (perbedaan), kepatuhan kepada orang tua, menghormati sesama, bekerja keras, bersikap rendah hati, dan menolong sesama (Burns, 2004:45). Hal ini relevan dengan pembelajaran delapan belas nilai pendidikan karakter bagi siswa. Anekdot ketika diceritakan dalam kegiatan pembelajaran oleh guru, dapat menjadikan suasana pembelajaran menyenangkan dan kondusif, karena membuat siswa tertawa, tetapi lebih dari itu, guru dapat menjadikannya sebagai cara mengajarkan nilai-nilai moral, seperti teks-teks anekdot karya Gus Dur.

Hasil penelitian mengenai nilai-nilai moral dalam teks anekdot Gus Dur memberikan implikasi terhadap pembelajaran teks anekdot di sekolah. Pembelajaran berbasis teks untuk mata pelajaran bahasa Indonesia Kurikulum 2013 memasukkan teks anekdot sebagai salah satu jenis teks yang dipelajari. Relevansi hasil penelitian mengenai nilai-nilai moral dalam teks anekdot Gus Dur dengan pengajaran teks anekdot bagi siswa di sekolah, yakni teks anekdot bukanlah sekedar cerita tanpa makna, namun sesungguhnya menyajikan nilai-nilai kehidupan, sehingga anekdot dapat dijadikan sumber pengajaran nilai moral atau kehidupan. Sebagai salah satu jenis teks yang dipelajari siswa, maka dalam silabus mata pelajaran bahasa Indonesia Kurikulum 2013 untuk siswa kelas X SMA terdapat Kompetensi Inti 3, di mana salah satu kompetensi dasar (KD) pembelajarannya yaitu "mengintepretasi makna teks enekdot". Tentu saja, dasar pemikiran teks anekdot diajarkan karena dapat dijadikan sarana untuk menyebarkan berbagai nilai kehidupan yang bertalian dengan moral, misalnya mengajarkan nilai kemajemukan (perbedaan), kepatuhan kepada peraturan, menghormati sesama, rendah hati, dan menolong sesama (Burns, 2004:45). Nilai-nilai ini terkandung pada teks anekdot Gus Dur yang dikaji dalam penelitian ini. Hal ini relevan dengan pembelajaran delapan belas nilai pendidikan karakter bagi siswa. Gus Dur yang pernah menjadi Presiden RI sekaligus sebagai kiyai dan ulama, menjadikan anekdot untuk memberi nasihat, mengeritik, dan menyindir. Gus Dur yang dijuluki Bapak Kemajemukan sering mengangkat tema toleransi, demokrasi, dan cinta kasih untuk disampaikan kepada khalayak ramai. 
Nilai-nilai seperti ini penting dipelajari siswa di sekolah untuk menumbuhkan dan mengembangkan sikap toleransi, demokratis, dan cinta kasih kepada sesama.

\section{KESIMPULAN}

Nilai-nilai moral yang terdapat dalam teks anekdot "Siapa yang Paling Hebat", yakni: keberanian, loyalital atau kesetian pada tugas, dan tidak boleh sombong. Nilai-nilai moral yang terdapat dalam teks anekdot "Sopir Metromini dan Juru Dakwah" siapun manusia di hadapan Tuhan sama dan tidak menjadi sombong rohani. Nilai-nilai moral dalam teks anekdot "Santri Dilarang Merokok" mematuhi aturan atau larangan dan membuktikan kesalahan seorang anak didik secara langsung. Nilai-nilai moral dalam teks anekdot "Dialog dangan Tuhan" adalah bersikap toleran, menghargai, dan menghormati keyakinan dan idiologi bangsa lain dan keyakinan orang lain adalah hal yang baik. Teks anekdot Gus Dur yang berjudul "DPR Turun Pangkat" yakni etika berbicara dan menghargai perbedaan pendapat.

Hasil penelitian mengenai nilai-nilai moral dalam teks anekdot Gus Dur memberikan implikasi terhadap pembelajaran teks anekdot di sekolah. Pembelajaran berbasis teks untuk mata pelajaran bahasa Indonesia Kurikulum 2013 memasukkan teks anekdot sebagai salah satu jenis teks yang dipelajari. Relevansi hasil penelitian mengenai nilai-nilai moral dalam teks anekdot Gus Dur dengan pengajaran teks anekdot karena menyajikan nilai-nilai kehidupan, sehingga anekdot dapat dijadikan sumber pengajaran nilai moral atau nilai kehidupan. Gus Dur yang pernah menjadi Presiden RI sekaligus sebagai kiyai dan ulama, menjadikan anekdot untuk memberi nasihat, mengeritik, dan menyindir. Gus Dur yang dijuluki Bapak Kemajemukan sering mengangkat tema toleransi, demokrasi, dan cinta kasih untuk disampaikan kepada khalayak ramai. Nilai-nilai seperti ini penting dipelajari siswa di sekolah untuk menumbuhkan dan mengembangkan sikap toleransi, demokratis, dan cinta kasih kepada sesama selaras dengan delapan belas pendidikan karakter dalam Kurikulum 2013.

\section{DAFTAR PUSTAKA}

Bagus, Lorens. 2000. Kamus Filsafat. Jakarta: PT Gramdedia Pustaka Utama.

Burns, G.W. 2004. 101 Kisah yang Memberdayakan, Penggunaan Metafora sebagai Media Penyembuhan. Bandung: Kaifa.

Dojosuroto, K . 2006. Analisis Teks Sastra dan Pengajarannya. Yogyakarta: Pustaka.

Greer R.J. 2009. Living with Integrity. Mememercayai, Mengatakan dan Melakukan yang Benar sesuai Panggilan Allah. Yogyakarta: Andi.

Kemendikbud, 2013. Kurikulum 2013. Kompetensi Dasar Sekolah Menengah Pertama dan Madrasah Tsanawiyah (MTs). Jakarta: Puskur.

Mahsun, M.S. 2014. Teks dalam dalam Pembelajaran Bahasa Indonesia Kurikulum 2013. Jakarta: PT Grafindo Persada.

Munsyi, A.D. 2012. Jadi Penulis? Siapa Takut!. Bandung: Kaifa.

Nusa Putra. 2011. Penelitian Kualitatif: Proses dan Aplikasi. Jakarta: PT Indeks.

Setiarini, I.W. \& Artini, MG Santi. 2018. Bahasa Indonesia SMA/MA Kelas X. Jakarta: Yudistira.

Wahyuni 2018. Humor dan Pesan Moral Teks Anekdot pada Buku Ajar Bahasa Indonesia Kelas X SMA Kurikulum2013. Repository Jurnal Ilmiah 